\title{
Indicators of health and safety among institutionalized older adults
}

\author{
Indicadores de saúde e a segurança do idoso institucionalizado \\ Indicadores sanitarios y la seguridad del anciano institucionalizado
}

\author{
Maria Lígia Silva Nunes Cavalcante ${ }^{1}$, Cíntia Lira Borges ${ }^{1,2}$, Acácia Maria Figueiredo Torres de Melo Moura ${ }^{3}$, Rhanna \\ Emanuela Fontenele Lima de Carvalho ${ }^{4}$
}

\section{How to cite this article:}

Cavalcante MLSN, Borges CL, Moura AMFTM, Carvalho REFL. Indicators of health and safety among institutionalized older adults. Rev Esc Enferm USP. 2016;50(4):600-606. DOI: http://dx.doi.org/10.1590/S0080-623420160000500009

\footnotetext{
${ }^{1}$ Universidade Estadual do Ceará, Programa de Pós-Graduação em Cuidados Clínicos em Enfermagem e Saúde, Fortaleza, Ceará, Brazil.

${ }^{2}$ Faculdade Maurício de Nassau,

Fortaleza, Ceará, Brazil.

${ }^{3}$ Hospital Cesar Calls, Fortaleza, Ceará, Brazil.

${ }^{4}$ Universidade Estadual do Ceará, Departamento de Enfermagem, Fortaleza, Ceará, Brazil.
}

\begin{abstract}
Objective: To identify the incidence of mortality, diarrheal diseases, scabies and falls; and the prevalence of pressure ulcers - all of which are related to the safety of institutionalized older adults. Method: This was a documentary retrospective study developed in a longterm residential care institution for older adults in the Northeast region of Brazil. The data were gathered from records of health assessment indicators filed between January 2008 and December 2015. Analysis included absolute case frequency; the sum of monthly prevalence and incidence rates; mean values of cases; and mean annual incidence and prevalence rates. Results: The incidence of mortality over these nine years ranged from $9 \%$ to $13 \%$; of acute diarrheic disease from $13 \%$ to $45 \%$; and scabies from $21 \%$ to $63 \%$. The prevalence of pressure ulcers ranged from 8\% to 23\%. Between 2012 and 2015, the incidence rate of falls without injury varied from $38 \%$ to $83 \%$, and with injury from $12 \%$ to $20 \%$. Conclusion: Analysis of the health indicators revealed a high incidence of scabies and falls and a high prevalence of pressure ulcers. The identification of less than optimal rates for performance indicators can help improve the quality of nursing care.
\end{abstract}

\section{DESCRIPTORS}

Aged; Patient Safety; Homes for the Aged; Geriatric Nursing; Health of Institutionalized Elderly; Health Status Indicators.

\section{Corresponding author:}

Maria Lígia Silva Nunes Cavalcante

Universidade Estadual do Ceará

Av. Dr. Silas Munguba, 1700, Campus do Itaperi

CEP 60714.903 - Fortaleza, CE, Brazil

mlsnc14@gmail.com
Received: 02/18/2016

Approved: 06/06/2016 


\section{INTRODUCTION}

The promotion of patient safety has gained global attention in recent years, being considered an essential strategy for healthcare quality ${ }^{(1)}$. Patient safety depends on both the characteristics of the institutional system, in terms of structures and processes, and the conditions of health professionals, such as adequacy of training and education, workload, and communication, all of which are crucial aspects that influence the occurrence of adverse events ${ }^{(2)}$.

Safe care must be valued as a patient right and must be part of the ethical commitment of professionals throughout the entire healthcare network. However, among such services, hospitals tend to be the main targets of patient safety actions, to the detriment of primary healthcare units, home care services, psychosocial support centers and long-term residential care institutions for older adults.

Patient safety culture must be addressed in all fields of nursing practice. In light of this, over the last decade, different initiatives have emerged to ensure safer health care. Among them, special mention goes to the creation of safety indicators that serve as a basis for controlling healthcarerelated adverse events ${ }^{(3)}$.

Brazil's current scenario includes the progressive growth of the older adult population and, consequently, greater demand for long-term care institutions, which are residential facilities with social and health services that provide comprehensive care ${ }^{(4)}$. In these facilities, older adults tend to be exposed to greater risks related to the unsuitable conditions of the physical structure and human and care-related resources. Such insufficiencies contribute to negative clinical outcomes, compromising the health condition of this population.

Therefore, considering the need to prevent and reduce health risks to which older adult residents are exposed in long-term care institutions, the Brazilian National Health Surveillance Agency (ANVISA, as per its acronym in Portuguese) established indicators to assess the performance and functioning standards of these facilities ${ }^{(4)}$. One of the requirements defined by ANVISA is the notification of some health indicators and sentinel events, considered mandatory for the monitoring of these institutions, namely: rates of death, diarrheal diseases, scabies, pressure ulcers, malnutrition, dehydration, falls and suicide attempts ${ }^{(4)}$. The assessment of these indicators via monthly records is crucial to establish goals aimed at reducing risks in the context of these institutions.

The retrospective review of institutional records has been considered the most adequate data collection method for evaluating adverse events. Thus, this method was adopted to identify the prevalence and incidence of these events, with the purpose of identifying preventable harm and intervening to ensure quality care and patient safety.

The aim of this study was to increase the existing scientific evidence on the theme, which is very limited and tends only to address isolated health indicators. The hypothesis is that an in-depth assessment of health indicators throughout the years will allow for a broader view of aspects involving the safety of institutionalized older adult patients. This has implications to the nursing and multidisciplinary teams in the creation of strategies for safe care and health promotion.

The role of nurses in clinical practice is to reduce risk and harm, incorporate good practices and make use of quality indicators via record systems. This contributes to care effectiveness and management, together with a change in culture, aligned with the national patient safety policy ${ }^{(1)}$.

Thus, the objective of this study was to identify the incidence of mortality, diarrheal diseases, scabies and falls, and the prevalence of pressure ulcers - in relation to the safety of institutionalized older adults.

\section{METHOD}

This was a quantitative, documentary and retrospective study in design, developed at a long-term residential care institution for older adults, located in the Northeast region of Brazil.

Currently, the facility houses 223 low-, medium- and high-income older adults, with a prevalence of those of low socioeconomic status. Patient age ranges from 60 to 101 years, and most are women. In terms of dependency, they are classified into one of three levels: level 1 (independent older adult), level 2 (difficulty carrying out at least three activities of daily living, preserved or slightly altered mental status) and level 3 (difficulty carrying out all self-care activities, and mental status alterations) $)^{(4)}$.

The data were gathered from administrative and health records and reports of the institution's assessment indicators as established by ANVISA via the Collegiate Board Resolution no. 283 of September 2005(4), filed between January 2008 and December 2015. Previous years were not considered, as the information available on the health indicators was incomplete.

To control the indicators established in the resolution, the selected institution has a standardized form that must be filled out on a monthly basis. The records are sent to the local health surveillance office every quarter. The institution's nurse coordinator is responsible for sending this indicator report.

In this study, the selected indicators were: mortality rate; incidence of diarrheal diseases and scabies; prevalence of pressure ulcers; and the sentinel event fall with injury. Falls without injury were also included.

Regarding the detection of scabies, suspicious injuries were observed by nursing technicians and caregivers and reported to the on-call nursing staff. The nurses then assessed the injury and analyzed the clinical signs or symptoms to establish the diagnosis together with the medical team composed of geriatric physicians. No specific tests were run, such as skin scraping or dermoscopy.

Diarrhea was defined as three episodes or more of loose or liquid stool occurring in a 24-hour period. Pressure ulcer risk was determined via the Braden scale ${ }^{(5)}$, and its presence was evaluated by the nursing staff and classified as stage 1 ulcer, with the emergence of a localized area of erythema, to stage 4 , in which deeper damage occurs to tissues, muscles and bones.

The institution possesses a notification form to report falls with or without injury, which is attached to patient 
charts and entered into an electronic spreadsheet, generated by Microsoft Excel, to control the inclusion of fall-related information and details on a monthly basis. The form and the spreadsheet contain general patient data, location and type of fall, characteristics of the injury, complementary information and necessary referrals. The role of the spreadsheet is to facilitate access to data when creating the institutional control reports. In this study, records of electronic spreadsheets regarding older adults who fell between 2012 and 2015 were considered, since the institution had no information before these years.

Even though ANVISA does not consider falls without injury in its evaluation, in this study, this type of event was included to interpret the magnitude of the problem at the facility. Furthermore, recurring falls, even without injuries, are an indicator of frailty and declining capacity and functional performance ${ }^{(6)}$.

The monthly calculation of each indicator has been standardized by ANVISA through its resolution. Thus, the incidence rate was calculated as the number of new cases in a given month/the number of resident older adults in that given month $\mathrm{x} 100(\%)$; and prevalence was calculated as the number of resident older adults who presented an event in a given month/the number of resident older adults in that month x 100 (\%).

The data were stored and analyzed using Microsoft Excel 2010. Tables were employed to describe the results, demonstrating absolute case frequency, the sum of monthly prevalence and incidence rates, mean case values, and annual incidence and prevalence rates.

The discussion addresses some of the events, difficulties, limitations and experiences related to the chosen institution, as the researchers work in the facility where the investigation took place; one for 35 years and the others for 5 years, with the exception of one researcher, who was essential for a neutral analysis and confrontation of the collected data. The discussion was formulated by combining the different knowledge and experience of each professional obtained in different periods.

This study abided by the ethical standards established for the evaluation of older and more recent documents, with the permission of the health coordinator and the president of the institution, as per resolution 466/12. The study was assessed and approved by the research ethics committee of Universidade Estadual do Ceará, under proposal CAAE: 12390513.8.0000.5534, resolution 305.456, amendment: 501.611.

\section{RESULTS}

The mean number of institutionalized adults at the studied facility in 2008 was $236.2( \pm 5.1)$; in $2009,225.75$ $( \pm 2.5) ; 2010,225.8( \pm 5.8) ; 2011,211.8( \pm 3.8) ; 2012,217.3$ $( \pm 2.38) ; 2013,229.3( \pm 7.0) ; 2014,222.2( \pm 1.7)$; and in $2015,228.7( \pm 6.0)$.

The tables show that mortality was higher in 2010, with a mean of three deaths per month; cases of acute diarrhea were more present in 2011, with a mean of eight cases per month; scabies obtained the highest incidence in 2008 (62.9\%); the annual prevalence rate of pressure ulcers was higher in 2013 (22.6\%). Considering falls, 2014 presented the highest number of cases, with 204 falls with and without injury; and 2015 was the year with the highest number of falls with injury (39) compared to the other years (Tables 1 and 2).

Table 1 - Distribution of new cases and the annual incidence rate of mortality, acute diarrhea, scabies; and prevalent cases and annual prevalence rate of pressure ulcers, at a long-term residential care institution for older adults, 2008 to 2011 - Fortaleza, Ceará, Brazil, 2015.

\begin{tabular}{|c|c|c|c|c|c|c|c|c|}
\hline \multirow{3}{*}{$\begin{array}{l}\text { Health } \\
\text { indicators }\end{array}$} & \multicolumn{8}{|c|}{ Period of record } \\
\hline & \multicolumn{2}{|c|}{2008} & \multicolumn{2}{|c|}{2009} & \multicolumn{2}{|c|}{2010} & \multicolumn{2}{|c|}{2011} \\
\hline & $\mathbf{f}^{1}$ & $T x^{2}$ & $f$ & $T x$ & f & $T x$ & f & $T x$ \\
\hline Mortality $^{3}$ & 27 & 11.4 & 28 & 11.1 & 36 & 11.4 & 25 & 11.7 \\
\hline $\begin{array}{l}\text { Acute } \\
\text { diarrhea }^{3}\end{array}$ & 32 & 13.5 & 45 & 19.7 & 55 & 24.8 & 96 & 44.8 \\
\hline Scabies $^{3}$ & 148 & 62.9 & 108 & 47.6 & 73 & 34.4 & 102 & 48 \\
\hline $\begin{array}{l}\text { Pressure } \\
\text { ulcer }^{4}\end{array}$ & 19 & 8.0 & 29 & 12.6 & 28 & 13.2 & 41 & 19.3 \\
\hline
\end{tabular}

Legend: 1: absolute frequency of cases per year; 2: total sum of monthly rates*100; 3: number of total incident cases per year and annual total incidence rate; 4 : total number of prevalent cases per year and total annual prevalence rate.

Table 2 - Distribution of the number of new cases and annual mortality incidence rate, acute diarrhea, scabies and falls; and prevalent cases and annual prevalence rate of pressure ulcers, at a long-term residential care institution for older adults, 2012 to 2015 - Fortaleza, Ceará, Brazil, 2015.

\begin{tabular}{|c|c|c|c|c|c|c|c|c|}
\hline \multirow{3}{*}{$\begin{array}{l}\text { Health } \\
\text { indicators }\end{array}$} & \multicolumn{8}{|c|}{ Period of record } \\
\hline & \multicolumn{2}{|c|}{2012} & \multicolumn{2}{|c|}{2013} & \multicolumn{2}{|c|}{2014} & \multicolumn{2}{|c|}{2015} \\
\hline & $\mathrm{f}$ & $T x$ & $\mathrm{f}$ & $T x$ & f & $T x$ & $\mathrm{f}$ & $T x$ \\
\hline Mortality & 24 & 11 & 30 & 13.1 & 21 & 9.4 & 24 & 10.4 \\
\hline $\begin{array}{l}\text { Acute } \\
\text { diarrhea }\end{array}$ & 33 & 15.2 & 49 & 21.6 & 87 & 39.3 & 23 & 10.2 \\
\hline Scabies & 54 & 25 & 51 & 22.2 & 48 & 21.7 & 50 & 21.3 \\
\hline $\begin{array}{l}\text { Pressure } \\
\text { ulcer }\end{array}$ & 26 & 12 & 52 & 22.6 & 37 & 16.6 & 30 & 13.1 \\
\hline $\begin{array}{l}\text { Fall without } \\
\text { injury }\end{array}$ & 85 & 38.9 & 132 & 57.9 & 184 & 82.8 & 98 & 43.0 \\
\hline $\begin{array}{l}\text { Fall with } \\
\text { injury }\end{array}$ & 27 & 12.4 & 33 & 14.4 & 20 & 9.0 & 39 & 17.1 \\
\hline
\end{tabular}

Tables 3 and 4 show that the mean total of deaths per year was evenly distributed throughout the entire period (two deaths/month), with the exception of 2010 (three deaths/month) and 2014 (one death/month). The mean number of diarrhea cases was higher in 2011 (eight cases/ month) and 2014 (seven cases/month). The mean incidence rate of scabies between 2008 and 2015 was 3\%; values higher than $3 \%$ are considered above average. Thus, the years 2008 (5.25\%), 2009 (3.9\%) and 2011 (4\%) obtained higherthan-average scabies rates. In terms of the prevalence of pressure ulcers, there was not much variation among the annual rates, with a mean of $1 \%$ throughout the entire period. 
Table 3 - Distribution of mean number of cases and annual prevalence and incidence rates of health indicators, at a long-term residential care institution for older adults, 2008 to 2011 - Fortaleza, Ceará, Brazil, 2015.

\begin{tabular}{|c|c|c|c|c|c|c|c|c|}
\hline \multirow{3}{*}{$\begin{array}{l}\text { Health } \\
\text { indicators }\end{array}$} & \multicolumn{8}{|c|}{ Period of record } \\
\hline & \multicolumn{2}{|c|}{2008} & \multicolumn{2}{|c|}{2009} & \multicolumn{2}{|c|}{2010} & \multicolumn{2}{|c|}{2011} \\
\hline & $\overline{\boldsymbol{x}}^{5}$ & $\overline{T_{x}}{ }^{6}$ & $\bar{x}$ & $\overline{T x}$ & $\bar{x}$ & $\overline{T X}$ & $\bar{x}$ & $\overline{T X}$ \\
\hline Mortality $^{7}$ & 2.2 & 0.9 & 2.3 & 0.9 & 3.0 & 0.9 & 2.0 & 0.9 \\
\hline $\begin{array}{l}\text { Acute } \\
\text { diarrhea }^{8}\end{array}$ & 2.6 & 1.1 & 3.7 & 1.6 & 4.6 & 2.0 & 8.0 & 3.7 \\
\hline Scabies $^{8}$ & 12 & 5.2 & 9.0 & 3.9 & 6.1 & 2.8 & 8.5 & 4.0 \\
\hline $\begin{array}{l}\text { Pressure } \\
\text { ulcer }^{9}\end{array}$ & 1.5 & 0.6 & 2.4 & 1.0 & 2.3 & 1.1 & 3.4 & 1.6 \\
\hline
\end{tabular}

Legend: 5: total mean number of cases per year; 6 : total mean rates per year*100; 7 annual mean mortality rate*100; 8: annual mean incidence rate*100; 9: annual mean prevalence rate ${ }^{*} 100$.

Regarding mean rate of falls, table 4 shows that 2013 (4.8\%) and 2014 (7.0\%) presented the highest rates of falls without injury. However, in 2012, 2013 and 2015 the mean number of new fall cases with injury remained above 2.1, with the exception of 2014 (1.6).

Table 4 - Distribution of mean number of cases and annual prevalence and incidence rates of health indicators, at a long-term residential care institution for older adults, 2012 to 2015 - Fortaleza, Ceará, Brazil, 2015.

\begin{tabular}{lccccccccc}
\hline & \multicolumn{10}{c}{ Period of record } \\
\cline { 2 - 9 } $\begin{array}{l}\text { Health } \\
\text { indicators }\end{array}$ & \multicolumn{2}{c}{$\mathbf{2 0 1 2}$} & \multicolumn{2}{c}{$\mathbf{2 0 1 3}$} & \multicolumn{2}{c}{$\mathbf{2 0 1 4}$} & \multicolumn{2}{c}{$\mathbf{2 0 1 5}$} \\
\cline { 2 - 9 } & $\overline{\boldsymbol{x}}$ & $\overline{\boldsymbol{T} \boldsymbol{x}}$ & $\overline{\boldsymbol{x}}$ & $\overline{\boldsymbol{T} \boldsymbol{x}}$ & $\overline{\boldsymbol{x}}$ & $\overline{\boldsymbol{T}}$ & $\overline{\boldsymbol{x}}$ & $\overline{\boldsymbol{T} \boldsymbol{x}}$ \\
\hline Mortality & 2.0 & 0.9 & 2.5 & 1.0 & 1.7 & 0.7 & 2.0 & 0.8 \\
$\begin{array}{l}\text { Acute } \\
\text { diarrhea }\end{array}$ & 2.7 & 1.3 & 4.0 & 1.8 & 7.2 & 3.3 & 2.0 & 0.8 \\
$\begin{array}{l}\text { Scabies } \\
\begin{array}{l}\text { Pressure } \\
\text { ulcer }\end{array}\end{array}$ & 4.5 & 2.1 & 4.2 & 1.8 & 4.0 & 1.8 & 4.2 & 1.7 \\
$\begin{array}{l}\text { Fall without } \\
\text { injury }\end{array}$ & 7.1 & 3.2 & 11 & 4.8 & 15.3 & 7.0 & 8.1 & 3.6 \\
$\begin{array}{l}\text { Fall with } \\
\text { injury }\end{array}$ & 2.2 & 1.0 & 2.1 & 0.9 & 1.6 & 0.8 & 3.2 & 1.4 \\
\hline
\end{tabular}

There was a gender difference in the number of falls in the years 2013 and 2015. In 2012, 56 (Tx: 25.71\%) falls were recorded among men and 56 ( $T x: 25.66 \%)$ among women. In 2013, 74 (Tx: 32.37\%) falls with and without injury were reported among men, and 91 ( $T x: 40.01 \%)$ among women. The year 2014 ended with 93 cases among men ( $T x: 41.91 \%)$ and 111 among women ( $T x: 49.93 \%)$; and 2015 with 66 cases ( $T x: 28.90 \%)$ among men and 71 $(T x: 31.24 \%)$ among women.

\section{DISCUSSION}

The mean incidence rate of mortality at the facility over the eight years was $11.2 \%$, which is considered high when compared to a study conducted in South Korea, in which the annual mean rate was $8.0 \%$. Mortality among institutionalized older adults can be associated with several different risk factors, among them cognitive and behavior disorders, disability, comorbidities, pressure ulcers and nutritional disorders ${ }^{(7-8)}$.

Recently-institutionalized older adults present a higher risk of death due to the increased probability of hospitalization $^{(8)}$. Health conditions that accelerate this process are similar to those that affect residents who have been at the facility for a longer time; among them dyspnea, malnutrition, dehydration and weight loss ${ }^{(7-9)}$.

Assessing the predicting factors of death for institutionalized older adults is complex, but clinically useful and valuable $^{(7)}$. For nursing, an analysis of the precursor signs is essential in order to define a long-term nursing plan aimed at reducing incidence of death in early stages and providing information about risk factors to multiprofessional teams ${ }^{(7)}$. Calculating the mortality rate provides a clinical indicator of patient safety, which contributes to more detailed verification and investigation of triggering problems and the optimization of the care provided.

In long-term residential care institutions in Brazil and worldwide $^{(10)}$, an important indicator used to assess health conditions is the incidence of acute diarrhea, which can be of lesser or greater severity. Despite the clinical signs, the etiology of diarrhea is difficult to define and its evolution depends on incubation period, eating habits, occupational risks, use of antibiotics, institutionalization, and immunological status ${ }^{(11)}$.

Diarrhea in institutions for older adults can represent a significant iatrogenic problem related to high rates of infection by cross contamination, especially due to inadequate hand hygiene, poor cleaning of shared utensils, inadequate sanitary conditions, and the improper use of medication, especially antibiotics. It can have multiple causes and be acute or chronic; of viral and/or bacterial origin; associated with food intolerance or allergies, or immunodeficiencies; secondary to fecolith and polypharmacy. Furthermore, one of the main causes of diarrhea, especially among institutionalized older adults, is the Clostridium Difficile bacteria, which is also responsible for elevated mortality rates ${ }^{(12)}$.

In the studied facility, the mean incidence rate of diarrhea over the eight years was $23.6 \%$, similar to the rate found in a study conducted in the United States, $27.4 \%$ over 16 years ${ }^{(13)}$. In the present institution, special mention goes to an outbreak of conjunctivitis and acute viral diarrhea in 2014 caused by rotavirus. It is believed that the situation was aggravated by poor hand hygiene and the incorrect use of personal protective equipment. In that year, both employees and resident older adults fell massively ill.

Cases of acute diarrhea must be notified so that longterm care institutions can create strategies to reduce rates of infection and improve the quality of the care provided. Recommended actions include immediate clinical and laboratory assessment in case of outbreaks; and initiating oral rehydration therapy and unrestricted diets ${ }^{(10)}$, with the exception of older adults with severe dehydration, who must receive intensified care.

The older adult population can sometimes neglect hygiene habits, whether because of lack of resources, cognitive 
impairment, depression or physical disability ${ }^{(14)}$. This can become more significant in long-term care institutions, as many older adults depend on their caregivers or the nursing team for bath orientation and supervision. However, at such facilities, the norm is one professional to 10 to 15 highly dependent patients; this ratio tends to lead to a situation in which professionals carry out bathing and skin hydration tasks automatically, with reduced attention to their importance in preventing skin infections and secondary dermatoses.

Skin and mucus diseases are important indicators to detect infections in long-term care institutions. Among them the most common are cellulite, pressure ulcers, scabies, mucocutaneous fungal infections, infections by the herpes virus and conjunctivitis ${ }^{(10)}$, which are the disorders most commonly seen in older adults. In this study, the incidence of scabies was as high as that of a study conducted in England in seven older adult institutions, in which the rate varied from $2 \%$ to $50 \%$, of which $95 \%$ were older adults with dementia, $79.5 \%$ with incontinence, and $61.5 \%$ with impaired mobility ${ }^{(15)}$.

Scabies is a contagious skin condition caused by a mite called Sarcoptes Scabiei, which affects humans by causing inflammatory and allergic reactions on the wrists, elbows, back, buttocks, external genital organs and fingers ${ }^{(14)}$. It is also known as the human itch mite and easily affects institutionalized older adults due to the ease of skin-to-skin transmission or via fomites, resulting in secondary infections and considerable worsening of quality of life, especially due to itching. Scabies is responsible for high morbidity rates and is strongly associated with the appearance of impetigo, abscesses and cellulite, which can lead to systemic complications, such as sepsis, kidney disease, and rheumatic heart disease ${ }^{(16)}$.

In this study, the rates reached more than half of the institutionalized older adults in the period between 2008 and 2011. Between 2012 and 2015, there was a reduction in the annual incidence rate. This may have been due to improved sanitary conditions; improved hygiene procedures of patient's clothes; increased amount of caregivers in the nursing wards; and periodic antiparasitic treatments, every six months. Even so, habits related to hand hygiene and changing clothes are still precarious among residents, which contributes to the rates of scabies remaining high.

Scabies is an overlooked, debilitating and unpleasant problem. Thus, there is an urgent need for support to allow for early recognition of outbreaks; and resources dedicated to training health teams to make diagnoses and management support protocols, including support from dermatology services, from directives that clearly establish the role and responsibility of each professional, and from the improvement of basic and primary care ${ }^{(15)}$.

Pressure ulcers represent a great health and economic problem faced by long-term care institutions for older adults ${ }^{(17)}$. The high rates presented here indicate the need for this event to be investigated, for in most cases, lesions can be avoided by the early detection of risk factors and the implementation of preventive measures ${ }^{(18)}$. The appearance of skin lesions has been used to assess the quality of care provision, and facilities that prevent are more highly recognized than those that treat ${ }^{(19)}$.

One of the risk factors for the appearance of lesions is old age ${ }^{(20)}$. Moreover, chronic-degenerative diseases, physical limitations, sarcopenia, malnutrition, frailty, disability and dependency are elements that can lead to patients being bedridden, making them even more susceptible to skin problems. Nurses are responsible for being familiar with the risk factors that cause this condition, enabling the creation of plans to promote safety actions for more vulnerable patients, thus increasing the overall quality of nursing care ${ }^{(18)}$.

Identifying the prevalence of pressure ulcers is an essential indicator in the assessment of nursing care. The prevalence rate of pressure ulcers in this investigation was similar to that of another study carried out in the Northeast region of Brazil, which ranged from $11.1 \%$ to $23.2 \%{ }^{(21)}$, rates that are considered high when compared to another study conducted in Holland, in which the rate was approximately $5 \%{ }^{(22)}$.

The institution in question deals with the everyday challenges limiting the implementation of actions that could reduce the appearance of pressure ulcers. Among them are insufficient nursing staff to care for older adults with severe level of dependency; precarious use of personal hygiene materials; inadequate diet; difficulties for introducing classification protocols and scales and lesion treatment; and lack of training and motivation for ongoing care.

Older adults with pressure ulcers present higher catabolism, which leads to malnutrition and higher risk of developing infections, contributing to higher mortality rates ${ }^{(23)}$. This becomes a chain of cascading events, the rates of which will represent patient safety indicators. Thus, it is important to simultaneously establish guidelines and orientation to prevent pressure ulcers, falls, malnutrition and infection to optimize basic nursing care and ensure the monitoring of adverse events and error ${ }^{(24)}$.

Falls constitute another sentinel event that warrants attention in long-term residential care institutions for older adults, and are considered a patient safety indicator ${ }^{(25)}$. The literature shows that one in every three older adults above the age of 65 falls at least once a year ${ }^{(26)}$.

In the studied institution, the mean incidence rate of falls with injury in the four selected years was $1.0 \%$, and falls without injury was $4.6 \%$. Similar results were found in a German study, which recorded a total fall rate of $4.6 \%$ in older adult homes in the last seven years ${ }^{(27)}$. The main risk factors compiled were associated with limited mobility, cognitive impairment, history of fall, and urinary incontinence ${ }^{(27)}$. Furthermore, women present greater predisposition for the risk of falls. It is believed that this occurs in virtue of improved functional condition of women in comparison with men, thus, they are more exposed to falls ${ }^{(28)}$.

The risk factors related to increased number of falls can be classified into one of two types: individual (intrinsic) predisposing factors such as age, clinical condition, gait and balance disorders, cognitive decline and decreased visual acuity; and environmental (extrinsic) factors such as insufficient lighting, inadequate stairways, absence of supporting bars in hallways and bathrooms, and wet surfaces ${ }^{(28)}$. 
In the studied institution, the main risk factors were related to environmental factors, such as wet surfaces, insufficient lighting and lack of support bars in some hallways. Also there is insufficient staff to meet the demands of the older adult residents, which hinders the monitoring of more independent patients by the health team. These patients present a higher level of activity and are therefore more exposed to the risk of falling.

Risk management practice by nurses is often insufficient to prevent falls ${ }^{(29)}$. In addition to risk management, institutions must contemplate an environment that fosters the well being and dignity of older adults, recognizing the complexity of promoting their safety when institutionalized ${ }^{(29)}$.

A study in Sweden revealed that merely $4 \%$ of the institutionalized older adults had not suffered falls, malnutrition or pressure ulcers ${ }^{(30)}$. This is to be expected, considering the dependency and frailty of most older adults residing in long-term care institutions. The study emphasizes the importance of nursing care with regards to monitoring health indicators, without disassociating them from other determinants of the patient's life, in order to define the status of risk and preventive and corrective actions for patient safety and promotion of quality of life.

Implementing protocols to perform multifactor risk assessment is one of the most effective strategies in the development of interventions for preventing and reducing the incidence of such events in long-term care residential institutions for older adults ${ }^{(29)}$. Concomitant to this assessment, another valuable tool is the promotion of health education actions, which have the purpose of encouraging responsibility for self-care among this population ${ }^{(28)}$. However, such strategies were not routine in the studied institutions and their practice can still be considered a challenge.

\section{CONCLUSION}

This study identified a high incidence of scabies and falls and a high prevalence of pressure ulcers among institutionalized older adults. The occurrence of these events was influenced by common factors: precarious sanitary conditions, insufficient nursing staff and number of caregivers, and lack of personal training.

In light of the above, special emphasis goes to simultaneous ongoing education for professionals and the institution on prevention guidelines and orientation to hone basic nursing care and ensure the monitoring of adverse events.

Limitations of this study refer to the lack of intervening variables, such as level of dependency, age and comorbidities, which did not allow for testing for intercorrelations and identifying possible confounding factors among the studied variables and health indicators.

It is important to conduct further studies on the identification of patient safety actions in the context of long-term residential care for older adults. The high rates of health indicators are a burden to the system, however, they could be easily reduced or avoided. Thus, the early investigation of risk factors and the implementation of preventive measures can contribute significantly to optimizing the service provided, nursing care and the quality of life of resident older adults.

\section{RESUMO}

Objetivo: Identificar a incidência de mortalidade, doenças diarreicas, escabiose e quedas, e a prevalência de lesões por pressão para a segurança do idoso institucionalizado. Método: Estudo documental, retrospectivo desenvolvido em uma Instituição de Longa Permanência para Idosos, localizada no nordeste do Brasil. Os dados foram coletados por meio dos registros dos indicadores de avaliação de saúde, arquivados de janeiro de 2008 a dezembro de 2015. A análise incluiu a frequência absoluta dos casos; o somatório das taxas de prevalência e incidência mensais; a média de casos e das taxas de incidência e prevalência anuais. Resultados: Observa-se que a incidência de óbitos nos nove anos considerados variou de 9 a 13\%; de doenças diarreicas agudas, de 13 a $45 \%$; e de escabiose, de 21 a 63\%. A prevalência de lesão por pressão oscilou de 8 a 23\%. Entre os anos de 2012 a 2015, a taxa de incidência de quedas sem lesão variou em torno de 38 a 83\%, e com lesão, de 12 a 20\%. Conclusão: A análise da amplitude dos indicadores de saúde permitiu identificar a alta incidência de escabiose e de quedas e a elevada prevalência de lesões por pressão. A identificação do comprometimento dos indicadores contribui para otimização da qualidade da assistência de enfermagem.

\section{DESCRITORES}

Idoso; Segurança do Paciente; Instituição de Longa Permanência para Idosos; Enfermagem Geriátrica; Saúde do Idoso Institucionalizado; Indicadores Básicos de Saúde.

\section{RESUMEN}

Objetivo: Identificar la incidencia de mortalidad, enfermedades diarreicas, escabiosis y caídas y la prevalencia de lesiones por presión para la seguridad del anciano institucionalizado. Método: Estudio documental, retrospectivo, desarrollado en un Institución de Larga Estancia para Ancianos, ubicada en el nordeste de Brasil. Los datos fueron recogidos por medio de los registros de indicadores de evaluación sanitaria, archivados de enero de 2008 a diciembre de 2015. El análisis incluyó la frecuencia absoluta de los casos; el sumatorio de las tasas de prevalencia e incidencia mensuales; el promedio y las tasas de incidencia y prevalencia anuales. Resultados: Se observa que la incidencia de defunciones en los nueve años considerados varió del 9 al 13\%; de enfermedades diarreicas agudas, del 13 al $45 \%$; y de escabiosis, del 21 al 63\%. La prevalencia de lesión por presión osciló del 8 al 23\%. Entre los años de 2012 a 2015, la tasa de incidencia de caídas sin lesión varió alrededor del 38 al 83\% y con lesión, del 12 al 20\%. Conclusión: El análisis de la amplitud de los indicadores sanitarios permitió identificar la alta incidencia de escabiosis y caídas y la elevada prevalencia de lesiones por presión. La identificación del compromiso de los indicadores contribuyó a la optimización de la calidad de la asistencia de enfermería.

\section{DESCRIPTORES}

Anciano; Seguridad del Paciente; Hogares para Ancianos; Enfermería Geriátrica; Salud del Anciano Institucionalizado; Indicadores de Salud. 


\section{REFERENCES}

1. Oliveira RM, Leitão IMTA, Silva LMS, Figueiredo SV, Sampaio RL, Gondim MM. Strategies for promoting patient safety: from the identification of the risks to the evidence-based practices. Esc Anna Nery. 2014;18(1):122-9.

2. Reis CT, Martins M, Laguardia J. A segurança do paciente como dimensão da qualidade do cuidado de saúde: um olhar sobre a literatura. Ciênc Saúde Coletiva. 2013;18(7):2029-36.

3. Asgari H, Esfahani SS, Yaghoubi M, Javadi M, Karimi S. Investigating selected patient safety indicators using medical records data. J Educ Health Promot. 2015; 4:54.

4. Brasil. Ministério da Saúde; Agência Nacional de Vigilância Sanitária. Resolução RDC $\mathrm{n}^{\circ}$ 283, de 26 de setembro de 2005 . Aprova o Regulamento Técnico que define normas de funcionamento para as Instituições de Longa Permanência para Idosos [Internet]. Brasília; 2005 [citado 2015 dez. 18]. Disponível em: http://bvsms.saude.gov.br/bvs/saudelegis/anvisa/2005/res0283_26_09_2005.html

5. Paranhos WY, Santos VL. Avaliação de risco para úlceras de pressão por meio da escala de Braden, na língua portuguesa. Rev Esc Enferm USP [Internet]. 1999 [citado 2015 dez. 18];33(n.esp):191-204. Disponível em: http://www.ee.usp.br/reeusp/upload/pdf/799.pdf

6. Borges CL, Silva MJ, Clares JW, Bessa ME, Freitas MC. Frailty assessment of institutionalized elderly. Acta Paul Enferm. 2013;26(4):318-22.

7. Sung K. Predictive factors associated with death of elderly in nursing homes. Asian Nurs Res. 2014;8(2):143-9.

8. Thomas JM, Cooney LM Jr, Fried TR. Systematic review: health-related characteristics of elderly hospitalized adults and nursing home residents associated with short-term mortality. J Am Geriatr Soc. 2013;61(6):902-11.

9. Brink P, Kelley ML. Death in long-term care: a brief report examining factors associated with death within 31 days of assessment. Paliat Care. 2015;9:1-5.

10. Stone ND, Ashraf MS, Calder J,Crnich, CJ, Crossley K, Drinka PJ, et al. Surveillance definitions of infections in long-term care facilities: revisiting the McGeer criteria. Infect Control Hosp Epidemiol. 2012;33(10):965-77.

11. Farthing M, Salam MA, Lindberg G, Dite P, Khalif I, Salazar-Lindo E, et al. Acute care diarrhea in adults and children: a global perspective. J Clin Gastroenterol. 2013; 47(1):12-20.

12. Chopra T, Goldstein EJC. Clostridium difficile infection in long-term care facilities: a call to action for antimicrobial stewardship. Clin Infect Dis. 2015;60 Suppl 2:S72-6.

13. Scallan E, Crim SM, Runkle A, Henao OL, Mahon BE, Hoekstra RM, et al. Bacterial enteric infections among older adults in the United States. Foodborne Pathog Dis. 2015;12(6):492-9.

14. Panuganti B, Tarbox M. Evaluation and management of pruritus and scabies in the elderly population. Clin Geriatr Med. 2013;29(2):479-99.

15. Hewitt KA, Nalabanda A, Cassell JA. Scabies outbreaks in residential care homes: factors associated with late recognition, burden and impact. A mixed methods study in England. Epidemiol Infect. 2015;143(7):1542-51.

16. Romani L, Koroivueta J, Steer AC, Kama M, Kaldor JM, Wand H, et al. Scabies and impetigo prevalence and risk factors in Fiji: a national survey. PLoS Negl Trop Dis. 2015;9(3):e0003474.

17. Olsho LE, Spector WD, Williams CS, Rhodes W, Fink RV, Limcangco R, et al. Evaluation of AHRQ's on-time pressure ulcer prevention program: a facilitator-assisted clinical decision support intervention for nursing homes. Med Care. 2014;52(3):258-66.

18. Santos CT, Almeida MA, Oliveira MC, Victor MAG, Lucena AF. Development of the nursing diagnosis risk for pressure ulcer. Rev Gaúcha Enferm [Internet]. 2015 [cited 2015 Dec 18];36(2):113-21. Available from: http://www.scielo.br/pdf/rgenf/v36n2/1983-1447rgenf-36-02-00113.pdf

19. Campanili TCGF, Santos VLCG, Strazzieri-Pulido KC, Thomaz PBM, Nogueira PC. Incidence of pressure ulcers in cardiopulmonary intensive care unit patients. Rev Esc Enferm USP [Internet]. 2015 [cited 2015 Dec 18];49(n.spe):7-13. Available from: http://www.scielo. br/pdf/reeusp/v49nspe/en_1980-220X-reeusp-49-spe-0007.pdf

20. Moraes GLA, Araújo TM, Caetano JA, Lopes MVO, Silva MJ. Evaluation of the risk for pressure ulcers in bedridden elderly at home. Acta Paul Enferm. 2012;25(n.spe 1):7-12.

21. Freitas MC, Medeiros ABF, Guedes MVC, Almeida PC, Galiza FT, Nogueira JM. Lesão por pressão em idosos institucionalizados: análise da prevalência e fatores de risco. Rev Gaúcha Enferm. 2011;32(1):143-50.

22. Meesterberends E, Halfens RJ, Spreeuwenberg MD, Ambergen TA, Lohrmann C, Neyens JC, et al. Do patients in Dutch nursing homes have more pressure ulcers than patients in German nursing homes? A prospective multicenter cohort study. J Am Med Dir Assoc. 2013;14(8):60510.

23. Martins AS, Rezende NA, Torres HOG. Sobrevida e complicações em idosos com doenças neurológicas em nutrição enteral. Rev Assoc Med Bras. 2012;58(6):691-97.

24. Van Gaal BG, Schoonhoven L, Mintjes-de Groot JA, Defloor T, Habets H, Voss A, et al. Concurrent incidence of adverse events in hospitals and nursing homes. J Nurs Scholarsh. 2014;46(3):187-98.

25. Clancy A, Mahler M. Nursing staffs' attentiveness to older adults falling in residential care: an interview study. J Clin Nurs. 2016;25(910):1405-15.

26. Morrison A, Fan T, Sen SS, Weisenfluh L. Epidemiology of falls and osteoporotic fractures: a systematic review. Clinicoecon Outcomes Res. 2013;5:9-18.

27. Lahmann NA, Heinze C, Rommel A. Falls in German hospitals and nursing homes 2006-2013. Frequencies, injuries, risk assessment, and preventive measures [abstract]. Bundesgesundheitsblatt-Gesundheitsforschung-Gesundheitsschutz. 2014;57(6):650-9.

28. Gomes EC, Marques AP, Leal MC, Barros BP. Factors associated with the danger of accidental falls among institutionalized elderly individuals: an integrative review. Ciênc Saúde Coletiva. 2014;19(8):3543-51.

29. Álvarez Barbosa F, Del Pozo-Cruz B, Del Pozo-Cruz J, Alfonso-Rosa RM, Sañudo Corrales B, Rogers ME. Factors associated with the risk of falls of nursing home residents aged 80 or older. Rehabil Nurs. 2016;41(1):16-25.

30. Lannering C, Ernsth Bravell M, Midlöv P, Östgren CJ, Mölstad S. Factors related to falls, weight-loss and pressure ulcers - more insight in risk assessment among nursing home residents. J Clin Nurs. 2016;25(7-8):940-50. 